\title{
Carotenoid pigments in microzooplankton
}

\author{
G. S. Kleppel ${ }^{1}$, Evelyn J. Lessard ${ }^{2}$ \\ ${ }^{1}$ Nova University Oceanographic Center, 8000 North Ocean Drive, Dania, Florida 33004, USA \\ ${ }^{2}$ School of Oceanography, University of Washington, Seattle, Washington 98195, USA
}

\begin{abstract}
The carotenoid pigments astaxanthin and canthaxanthin were measured in cultured and field-collected heterotrophic dinoflagellates ( 2 species), ciliates ( 3 species) and copepod eggs (1 species). The heterotrophic dinoflagellates contained either astaxanthin or canthaxanthin as a single dominant pigment. Conversely, the choreotrichous ciliates contained both carotenoids. A small amount of canthaxanthin was detected only at high concentrations in the oligotrich Strombidium sp. Copepod eggs contained astaxanthin and xanthophyll esters. The esters were not detected in the protozoans. Cellular pigment content varied both within and between taxonomic groups, but was low compared with phytoplankton. Microzooplankton which have low C:carotenoid ratios (e.g. some dinoflagellates), and large organisms, even when not heavily pigmented (e.g. Favella ehrenbergii) are readily detected by carotenoid analysis. Small, weakly pigmented ciliates, however, are more difficult to detect when they are present in low concentrations. The pigment content of a heterotrophic dinoflagellate (Gymnodinium sp.) cultured at $29 \mu \mathrm{E} \mathrm{m}^{-2} \mathrm{~s}^{-1}$ (low-light group) was approximately $42 \%$ of the average pigment content of the same species cultured in the same food environment but at $290 \mu \mathrm{E} \mathrm{m}^{-2} \mathrm{~s}^{-1}$ (highlight group). Inadvertent starvation of the cultures in the low-light group for $\leq 3 \mathrm{~d}$ resulted in the loss of all measureable pigmentation.
\end{abstract}

\section{INTRODUCTION}

Carotenoid pigments occur in representives of all phyla of marine organisms (Goodwin 1976) and are widely distributed among the zooplankton and micronekton (Cheeseman et al. 1967, Herring 1972). The carotenoids astaxanthin and canthaxanthin are common in metazoans (Castillo et al. 1982), and have been reported in trace concentrations in a few types of phytoplankton (Liaenn-Jensen 1979). They are thought to be photoprotective (Hairston 1979) and may have metabolic roles as well (Cheeseman et al. 1967, Byron 1982).

Certain carotenoids are restricted to specific taxonomic groups and, as such, are widely used as markers for coarsely describing plankton assemblages (Strain et al. 1944, Mantoura \& Llewellyn 1983, Smith et al. 1987. Kleppel 1988). In addition, carotenoid content is roughly proportional to the biomass of bacteria (Liaaen-Jensen 1979) and phytoplankton (Burkill et al. 1987). A general proportionality was also reported between microzooplankton biomass and carotenoid pigment content, though the distribution and composition of pigments within taxa was not specified (Kleppel et al. 1988).
Most research on zooplankton pigmentation has focused on metazoans, notably the crustaceans (Herring 1968, Hairston 1979, Castillo et al. 1982). Systematic studies of microzooplankton pigmentation are scarce, especially for the protozoans. To our knowledge, the carotenoids of heterotrophic ciliates have not been described, although chlorophyll and phycoerythrin from sequestered chloroplasts of ingested algae have been documented (McManus \& Fuhrman 1986, Stoecker et al. 1987). Carotenoid pigmentation in heterotrophic dinoflagellates, as distinct from their photosynthetic counterparts, has been discussed in several papers (Neveaux \& Soyer 1976, Withers \& Haxo 1978, Balch \& Haxo 1984, Carreto 1985) though the amount of information on these pigments and their significance is small compared to the data on metazoan pigmentation.

The lack of information on protozoan pigmentation is not surprising given that the abundance, diversity and trophic importance of these organisms in the sea has only recently been recognized (e.g. see recent reviews by Sherr et al. 1986, Stoecker \& Capuzzo 1990, Lessard 1991, and references thereinj. Ultimately, pigments 
may be useful for describing microzooplankton distributions and understanding the physiology of these organisms.

In this paper we describe the pigments of cultured and field-collected microzooplankton (defined here as protozoans and metazoans smaller than $200 \mu \mathrm{m}$ in diameter). The taxa that we have examined are typical representatives of the coastal microfauna. We also present the results of an experiment which examined the effects of light intensity on protozoan pigmentation.

\section{MATERIALS AND METHODS}

Two sets of measurements were performed. The first consisted of a general screening of pigments in 4 representative protozoan taxa. These were an athecate, heterotrophic dinoflagellate, Gymnodinium sp.; an aloricate, oligotrichous ciliate, Strombidium sp.; an aloricate choreotrichous ciliate, Stombidinopsis sp.; and a loricate choreotrich, Favella ehrenbergii, grown in culture. For comparative purposes, data on the pigments in copepod eggs and field-caught specimens of the thecate, heterotrophic dinoflagellate Protoperidinium sp. were described. The second set of measurements was performed to evaluate the differential effects of light intensity on pigment content in Gymnodinium sp

Cultures were kindly provided by S. Strom and maintained on algal food mixtures in seawater with $\mathrm{f} / 2$ trace metals added (with $10^{-7} \mathrm{M}$ EDTA; Gifford 1985). The food algae, maintained in $\mathrm{f} / 2$ minus $\mathrm{Si}_{\text {, }}$ consisted of Isochrysis galbana (I), Chroomonas sp. (C), photosynthetic Gymnodinium sp. (G), and Synechococcus sp. (S). Mixtures of $\mathrm{I}, \mathrm{C}$ and $\mathrm{G}$ were fed to Favella ehrenbergii and Strombidinopsis sp. I, C, G and $S$ were fed to Strombidium sp. and I and S were fed to Gymnodinium sp. At the beginning of each experiment, inocula from stock cultures were transfered to fresh medium, and mixtures of exponentially growing food organisms were added (at ca $100 \mu \mathrm{g} \mathrm{C} \mathrm{l^{-1 }}$ each). The cultures were incubated at $13^{\circ} \mathrm{C}$ under cool white, fluorescent lights, on a $14 \mathrm{~h} / 10 \mathrm{~h}$ light/ dark cycle. For general pigment screening (the first set of measurements), light intensity was $29 \mu \mathrm{E} \mathrm{m}^{-2} \mathrm{~s}^{-1}$. To study the response of Gymnodinium to different light intensities (the second set), cultures were grown at 29 and $290 \mu \mathrm{E} \mathrm{m}^{-2} \mathrm{~s}^{-1}$. During pigment screening, cultures were harvested $7 \mathrm{~d}$ after feeding. During the differential light-intensity experiment, triplicate $80 \mathrm{ml}$ subsamples from each of 3 replicate cultures ( 9 analyses at each light intensity) exposed to each light regime were harvested $10 \mathrm{~d}$ after feeding. These are referred to as $\mathrm{HA}, \mathrm{HB}, \mathrm{HC}$ (high-light) and LA, LB, LC (low-light)
For pigment screening, samples of varying volume (usually 3 different volumes), representing different biomasses (Table 1), were prepared from each culture. These were concentrated under gentle vacuum (<5 $\mathrm{mm} \mathrm{Hg}$ ) onto Whatman GF/F filters. The filters were stored in liquid nitrogen prior to shipment from the culturing facility (Seattle, Washington, USA) to the analytical laboratory (Dania, Florida, USA). The samples were shipped on dry ice and returned to liquid nitrogen within $24 \mathrm{~h}$. Analyses were performed within 2 mo. Samples for cell counting and biovolume estimates were preserved with acid Lugol's iodine solution. Carbon content was determined by using the conversion $0.19 \mathrm{pg} \mathrm{C} \mathrm{um}{ }^{-3}$ (Putt \& Stoecker 1989). In general, we chose not to attempt mechanical separation of the protozoans from their food as this would in. crease the risk of damaging the delicate cells. Instead, we chromatographed cultures of food without protozoa and identified the protozoan pigments in experimental (protozoa and food) cultures by process of elimination.

Protoperidinium sp. (740 cells) were individually pipetted from a sample collected by towing a plankton net ( $26 \mu \mathrm{m}$ Nitex mesh, $0.50 \mathrm{~m}$ mouth diameter) just below the surface at Port Everglades Inlet, Florida $\left(26.3^{\circ} \mathrm{N}, 80.06^{\circ} \mathrm{W}\right)$ in November 1987 . The sample was analyzed within $5 \mathrm{~h}$ of collection.

Copepad eggs were obtained by pipetting 24 adult female Acartia tonsa into each of three 21 bottles containing $0.22 \mu \mathrm{m}$ filtered seawater. The copepods were placed in a darkened incubator at ambient temperature for $12 \mathrm{~h}$, after which the adults were removed from the containers and the eggs were collected on $35 \mu \mathrm{m}$ mesh screens. The material on each screen was washed onto a Whatman GF/C filter and frozen in liquid nitrogen pending analysis.

For both sets of measurements, pigments were measured by reverse phase, high performance liquid chromatography (HPLC). Analyses were performed in a cool, dimly lit room with chromatography grade reagents (EM Omnisolve). The approach was described by Kleppel et al. (1988). Each sample on a frozen filter was macerated by hand, in a glass tissue grinder in $90 \%$ aqueous acetone and refrigerated $\left(5^{\circ} \mathrm{C}\right)$ for $45 \mathrm{~min}$ to permit extraction of pigments. The sample was cleared of particulates by centrifugation (5000 rpm for $5 \mathrm{~min}$ ). The extract was decanted, an ion pairing agent was added (Solution P; Mantoura \& Llewellyn 1983) at $0.3 \mathrm{ml}$ Solution P per ml of extract, and the extract was recentrifuged for $5 \mathrm{~min}$. The extract was then injected onto a Beckman C-8 octyl ultrasphere $(5 \mu \mathrm{m})$, monomeric reverse phase column ( $4.5 \mathrm{~mm} \times 15 \mathrm{~cm}$ stainless steel), protected by a stainless steel guard column, packed with ultrasphere octyl $(10 \mu \mathrm{m})$ material. Pigments were eluted under a 2-solvent (A and B) mobile phase delivered along a continuous gradient from $80 \% \mathrm{~B}: 20 \% \mathrm{~A}$ 
Table 1. Biomass characteristics and pigments of microzooplankton considered in this study. ND: not detected or uncertain identification, not included in analysis; -: no data or not appropiate

\begin{tabular}{|c|c|c|c|c|c|c|}
\hline \multirow[t]{2}{*}{ Species } & \multirow{2}{*}{$\begin{array}{c}\text { Sub- } \\
\text { sample }\end{array}$} & \multirow{2}{*}{$\begin{array}{l}\text { Cell C } \\
\text { (pg) }\end{array}$} & \multirow{2}{*}{$\begin{array}{c}\text { Total C } \\
\text { (ng) }\end{array}$} & \multicolumn{2}{|c|}{ Pigment (pg cell ${ }^{-1}$ ) } & \multirow{2}{*}{$\begin{array}{c}\mathrm{C}: \text { carotenoid } \\
\text { ratio }\end{array}$} \\
\hline & & & & Canthaxanthin & Astaxanthin & \\
\hline \multirow{5}{*}{$\begin{array}{l}\text { Gymnodinium sp. } \\
\text { (naked, } \\
\text { heterotrophic } \\
\text { dinoflagellate) }\end{array}$} & 1 & 0.19 & 29 & ND & ND & - \\
\hline & 2 & 0.19 & 288 & 2.23 & ND & 129.1 \\
\hline & 3 & 0.19 & 2888 & 1.71 & ND & 111.1 \\
\hline & Mean & & & 1.97 & & 120.1 \\
\hline & $\mathrm{SD}$ & & & 0.26 & & 9.0 \\
\hline \multirow{5}{*}{$\begin{array}{l}\text { Strombidium sp. } \\
\quad \text { (aloricate, } \\
\text { oligotrichous } \\
\text { ciliate) }\end{array}$} & 1 & 2.35 & 2585 & ND & ND & - \\
\hline & 2 & 2.35 & 6463 & ND & ND & - \\
\hline & 3 & 2.35 & 12925 & ND & 0.05 & $4.7 \times 10^{4}$ \\
\hline & Mean & & & - & 0.05 & - \\
\hline & $\mathrm{SD}$ & & & - & - & - \\
\hline \multirow{5}{*}{$\begin{array}{l}\text { Strombidinopsis sp. } \\
\text { (aloricate, } \\
\text { choreotrichous } \\
\text { ciliate) }\end{array}$} & 1 & 8.25 & 5775 & ND & ND & - \\
\hline & 2 & 8.25 & 11550 & 9.60 & 6.64 & 859.4 \\
\hline & 3 & 8.25 & 28182 & 16.00 & 5.78 & 515.6 \\
\hline & Mean & & & 12.80 & 6.21 & 687.5 \\
\hline & $\mathrm{SD}$ & & & 3.20 & 0.43 & 171.9 \\
\hline \multirow{5}{*}{$\begin{array}{l}\text { Favella ehrenbergii } \\
\text { (loricate, } \\
\text { choreotrichous } \\
\text { ciliate) }\end{array}$} & 1 & 26.00 & 9880 & 26.84 & ND & 968.7 \\
\hline & 2 & 26.00 & 24700 & 10.53 & 2.95 & 2469.1 \\
\hline & 3 & 26.00 & 49400 & 12.11 & 2.58 & 2147.0 \\
\hline & Mean & & & 16.49 & 2.77 & 1861.6 \\
\hline & $\mathrm{SD}$ & & & 7.34 & 0.19 & 644.9 \\
\hline $\begin{array}{l}\text { Protoperidinium sp. } \\
\text { (thecate, hetero- } \\
\text { trophic dinoflagellate) }\end{array}$ & 1 & - & ND & ND & 0.37 & - \\
\hline \multirow{5}{*}{$\begin{array}{l}\text { Acartia tonsa eggs } \\
\text { (calanoid } \\
\text { copepod) }\end{array}$} & 1 & 31.00 & 9300 & 342.40 & ND & 90.6 \\
\hline & 2 & 31.00 & 9300 & 320.00 & ND & 96.9 \\
\hline & 3 & 31.00 & 9300 & 297.60 & ND & 104.2 \\
\hline & Mean & & & 320.00 & & 97.2 \\
\hline & $\mathrm{SD}$ & & & 0.18 & & 5.6 \\
\hline
\end{tabular}

(v: v) to $100 \%$ B over 10 min. Solvent B was delivered for an additional $10 \mathrm{~min}$. Flow rate rose from 1.0 to $1.9 \mathrm{ml} \mathrm{min} \mathrm{min}^{-1}$ over the first $10 \mathrm{~min}$, and remained at $1.9 \mathrm{ml} \mathrm{min}{ }^{-1}$ thereafter. Solvent A consisted of an 8:1:1 solution of water:methanol: Solution $\mathrm{P}$; Solvent B was an $8: 2$ solution of methanol: acetone.

Chromatography was performed with a Waters gradient elution system consisting of paired pumps (model 501), linked to a model 680 gradient controller. Samples were injected into a U6K sampling module and eluting pigments were detected with a model 481 , variable wavelength $U V / v i s$ detector (usually set at $460 \mathrm{~nm}$ ). The signal was acquired by an OMS-Tech data processing system run on a 286-microprocessor that logged and plotted the chromatographic data, reported retention times and computed areas under peaks. In one case (Protoperidinium sp.), the data were processed with a Waters model 730 data module, instead of the OMS-Tech system. The Waters data module is not microprocessor interfaced.
To ensure unambiguous detection of animal carotenoids as many as 6 standards were run for each sample analyzed. Standards were usually chromatographed after each sample to ensure the validity of pigment retention times. Many samples were fractionated and chromatographed with and without standards (as internal spikes). Samples of the algae used as food in culture experiments were also chromatographed with and without the addition of astaxanthin and canthaxathin standards, to identify potential coelution problems. On some occasions astaxanthin seems to have coeluted with diadinoxanthin. Our intensive standardization protocol, however, permitted us to identify astaxanthin in most chromatograms and to detect and reject chromatograms in which co-elution occurred. The chromatographic protocol has subsequently been modified to obviate these problems.

Astaxanthin standards were prepared from live shrimp carapace and muscle tissue. Pigments were extracted in $90 \%$ aqueous acetone and chromato- 
graphed as described above. Astaxanthin was collected as it eluted, concentrated to dryness under nitrogen and resuspended in $90 \%$ aqueous acetone. Canthaxanthin standards, in $100 \%$ acetone, were stored in sealed amber vials at $-50{ }^{\circ} \mathrm{C}$ until use. When needed, a vial was opened in a nitrogen atmosphere and the contents were diluted to $90 \%$ aqueous acetone. Fresh astaxanthin was prepared approximately each week. Both pigment standards, once prepared, were stored at $-5^{\circ} \mathrm{C}$ in amber containers, under nitrogen. Standard authenticity was confirmed spectrophotometrically and with published chromatographic data (Table 2).

Quantification of pigments was achieved with empirically-derived relationships between areas under chromatogram peaks and pigment concentrations. The pigment concentrations used in developing these relationships were determined by spectrophotometric analysis of standards with the extinction coefficients given by Herring (1972) for astaxanthin and by Davies (1976) for canthaxanthin.

\section{RESULTS}

\section{Pigment screening}

Astaxanthin and canthaxanthin were never found in any of the algal food cultures. However, one or both pigments were detected in all of the microzooplankton species examined. Gymnodinium sp. contained canthaxanthin (Fig. 1a). Astaxanthin was the predominant carotenoid in the sample of Protoperidinium from Port Everglades, Florida (Fig. 1b); a trace of canthaxanthin was also detected. Several photosynthetic accessory pigments were also present in this sample. These would be contibuted by phytoplankton cells inadvertently included in the sample during sorting. Both carotenoids, astaxanthin and canthaxanthin, were present in the choreotrichous ciliates Favella ehrenbergii and Strombidinopsis sp.
(Fig. 1c, d). A small amount of canthaxanthin was detected in the most concentrated sample (12925 ng C; Table 1) of the oligotrich Strombidium sp. (Fig. 1e). Pigments were not detected at lower concentrations in this species. Copepod eggs (Fig. 1f) contained astaxanthin as well as pigments inferred to be xanthophyll esters (peaks 17) that were not detected in the protozoans.

Our ability to detect and quantify pigments in cultured protozoans varied with biomass and taxon (Table 1). Canthaxanthin was detected in approximately $288 \mathrm{ng}$ of Gymnodinium sp. carbon-biomass, but was not seen in Strombidinopsis sp. below $5800 \mathrm{ng}$ C-biomass. Strombidium sp. in our cultures was nearly devoid of carotenoids. The relationship between pigment content and biomass varied with species over more than 2 orders of magnitude. $C$ : carotenoid ratios ranged from ca 100 in copepod eggs and Gymnodinium sp., to about $4.7 \times 10^{4}$ in Strombidium sp. (Table 1).

\section{Effect of light intensity}

The results of the differential light-intensity experiment are shown in Fig. 2. At the high light intensity $\left(290 \mu \mathrm{E} \mathrm{m} \mathrm{m}^{-2} \mathrm{~s}^{-1}\right)$, between-culture differences in cell density, at the time of harvesting, were large. At low light intensity, cell densities were less variable between cultures. In culture HA, the available Gymnodinium sp. biomass $\left(6.6\right.$ cells $\mathrm{ml}^{-1}=$ ca $100 \mathrm{ng} \mathrm{C}$ per sample) was inadequate to provide detectable pigment.

No pigment was detected in cultures maintained at the lower light intensity in this experiment (Fig. 2), though cell densities were sufficient to detect canthaxanthin (Table 1). An additional identical culture (LD) was incubated at $29 \mu \mathrm{E} \mathrm{m}^{-2} \mathrm{~s}^{-1}$, but harvested 7 (instead of 10) $d$ after feeding, as in the screening studies. Gymnodinium sp. density in this culture reached 606 cells $\mathrm{ml}^{-1}$ similar to other low-light cultures. Unlike

Table 2. Spectral and chromatographic characteristics of astaxanthin and canthaxanthin. $E^{1 \%}$ : published extinction coefficient; -: comparison is made between published absorbance maxima and those observed in the present study; $k^{\prime}$ : capacity factor, determined from retention time, $T_{\mathrm{R}}$ and time to elution of the unretained fraction, $T_{0}, k^{\prime}=\left(T_{\mathrm{R}}-T_{0}\right) / T_{0}$ (Snyder \& Kirkland 1979); the number of theoretical plates is determined empirically, and represents the efficiency of the column for resolving a given pigment

\begin{tabular}{|c|c|c|c|c|c|c|}
\hline \multirow[t]{2}{*}{ Pigment } & \multirow[t]{2}{*}{$E^{1 \%}$} & \multicolumn{2}{|c|}{ Absorbance maxima } & \multirow[t]{2}{*}{ Solvent } & \multirow[t]{2}{*}{$k^{\prime}$} & \multirow{2}{*}{$\begin{array}{l}\text { No. of } \\
\text { theoretical plates }\end{array}$} \\
\hline & & Published & Observed & & & \\
\hline Astaxanthin & $2099^{d}$ & $480^{b}$ & 479 & Acetone & 2.47 & 69158 \\
\hline Canthaxanthin & $2096^{b}$ & $467^{\circ}$ & 467 & Hexane & 3.53 & 70543 \\
\hline
\end{tabular}



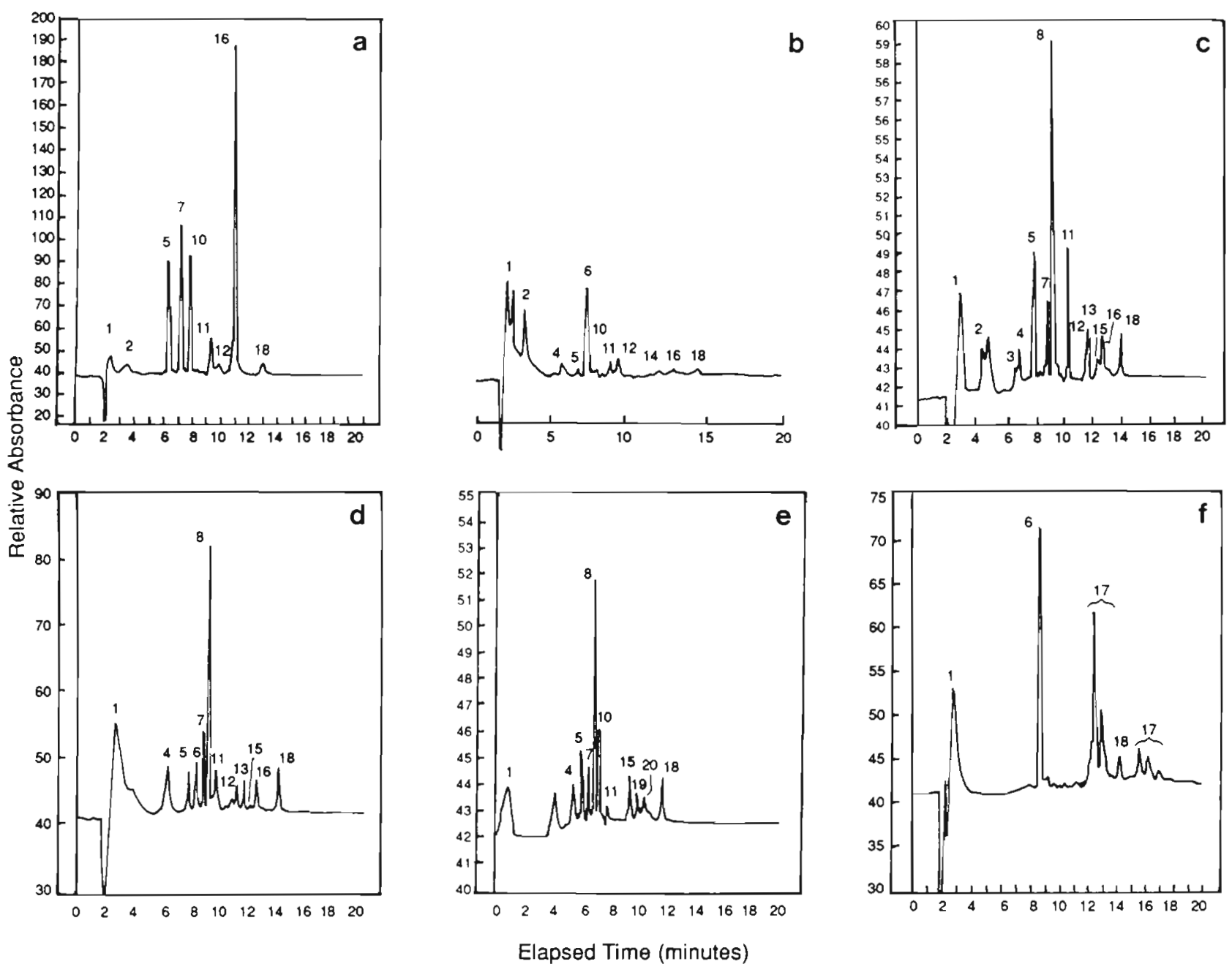

Fig. 1. Chromatograms of pigments from (a) a cultured heterotrophic dinoflagellate, Gymnodinium sp., (b) another heterotrophic dinoflagellate, Protoperidinium sp., sorted from plankton tows in a Florida estuary, (c to e) cultures of the ciliates Favella ehrenbergii, Strombidinopsis sp., and Strombidium sp. and (f) the eggs of the copepod Acartia tonsa. Note that all chromatograms except (b) were stored to disc using OMS-Tech integrator and processed for presentation using standard spreadsheet software. Chromatogram (b) was traced from hard copy provided by Waters 730 data module. Pigments: 1 , unretained fraction; 2, chlorophyll $c\left(c_{1}, c_{2}\right.$, or both $)$ 3, peridinin-like pigment; 4, peridinin; 5 , fucoxanthin; 6 , astaxanthin; 7 , diadinoxanthin; 8, alloxanthin, 9, diatoxanthin; 10 , zeaxanthin; 11 , canthaxanthin; 12 , unidentified; 13 , unidentified; 14 , chlorophyll $b ; 15$, chlorophyll $a$ allomer; 16, chlorophyll a; 17 , xanthophyll esters; 18 , beta-carotene; 19 , unidentified; 20 , unidentified

the other low-light cultures, canthaxanthin was present in this culture. Cellular canthaxanthin data from the LD culture was combined with canthaxanthin concentrations from Gymnodinium sp. in the pigment screening measurements to generate an average, low-light concentration (mean $\pm \mathrm{SD}$ ) of $1.57 \pm 0.60 \mathrm{pg} \mathrm{cell}^{-1}$. This mean was $42 \%$ of the average high-light pigment concentration $\left(3.72 \pm 2.61 \mathrm{pg}\right.$ cell $\left.{ }^{-1}\right)$.

Also shown in Fig. 2 is the concentration of chlorophyll a present in the cultures at the time of harvesting. Chlorophyll $a$ was used to provide an indication of algal biomass availabie as food to the heterotrophic Gymnodinium sp. Except for culture HA, in which
Gymnodinium sp. cell densities were below the pigment-detection threshold, mean cellular canthaxanthin levels in the dinoflagellate covaried with chlorophyll concentrations in the food supply. Chlorophyll concentrations were higher in cultures exposed to high light intensity than in cultures exposed to low light intensity. Chlorophyll was not detected in those cultures incubated for $10 \mathrm{~d}$ at low light intensity ( $\mathrm{LA}, \mathrm{LB}, \mathrm{LC}$ ), where Gymnodinium sp. was abundant but lacked measurable canthaxanthin. Chlorophyll was present in the low-light culture which was harvested after $7 \mathrm{~d}$ (LD). Apparently, the food supply was exhausted between Days 7 and 10. 


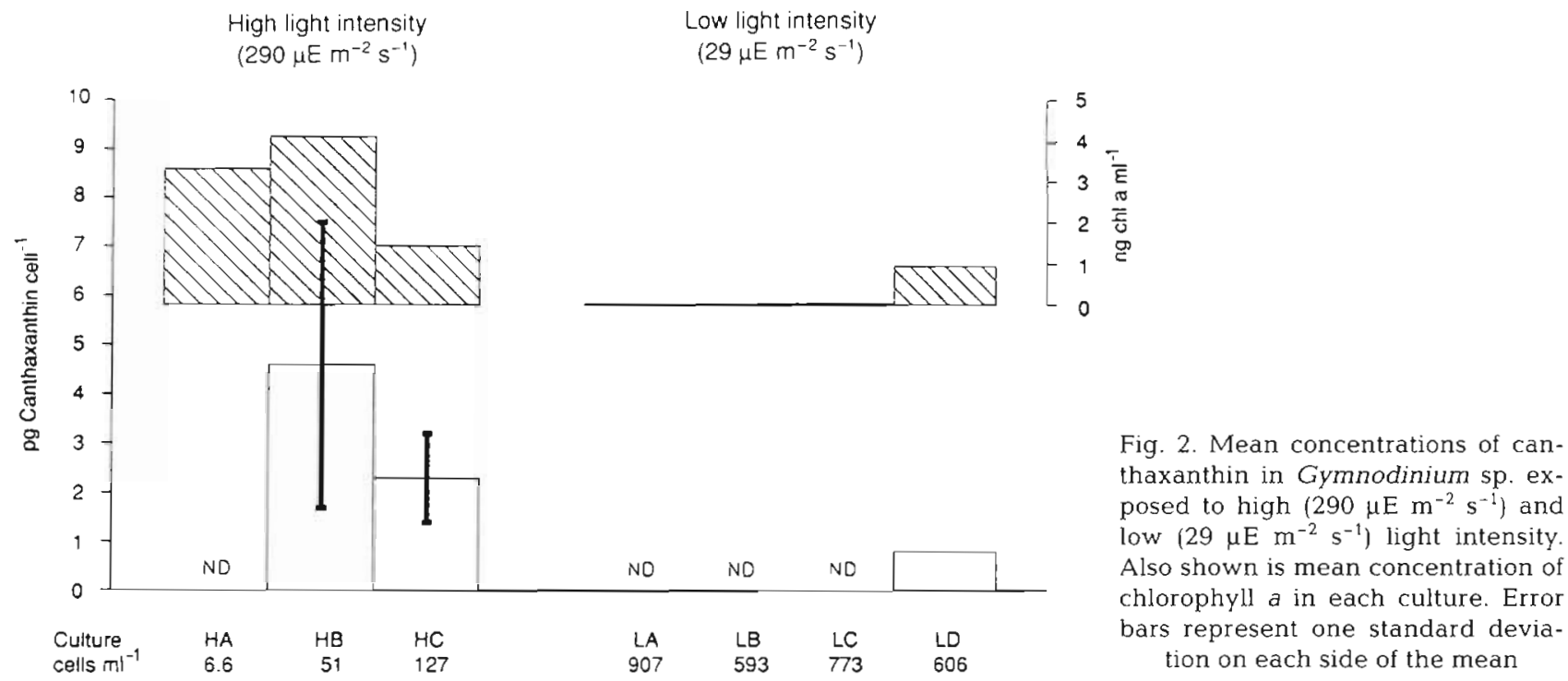

\section{DISCUSSION}

\section{Pigment screening}

It is evident that carotenoid pigments, which are well known in metazoans, also occur in a variety of protozoans. Although astaxanthin and canthaxanthin have been detected in trace amounts in some marine phototrophs (Liaenn-Jensen 1978), these pigments appear to be characteristic of heterotrophic organisms. Astaxanthin is more common than canthaxanthin among metazoans, but both pigments were detected in ciliates and heterotrophic dinoflagellates. Our observation that the heterotrophic dinoflagellates Gymnodinium sp. and Protoperidinium sp. contain canthaxanthin and astaxanthin are consistent with observations on the occurrence of these pigments in other heterotrophic dinoflagellates [(Protoperidinium ovatum: Neveaux \& Soyer (1976); Peridinium foliaceum: Withers \& Haxo (1978); Noctiluca miliaris: Balch \& Haxo (1984); Protoperidinium depressum: Carretto (1985)]. To our knowledge, this is the first report of these pigments in marine ciliates. Xanthophyll esters were detected in copepod eggs but not in the protozoans that we screened for pigments. Further studies will focus on determining whether the presence of xanthophyll esters distinguishes metazoans from protozoans.

Relative to algal cells, most heterotrophs are rather weakly pigmented. Phytoplankton C:carotenoid ratios range from tens to hundreds (Kleppel et al. 1988); ratios for the microzooplankton studied here ranged from hundreds to thousands or higher. The ability to detect pigments in microzooplankton is, naturally, determined by sample size (i.e. amount of biomass in the sample) and by the $\mathrm{C}$ : carotenoid ratio. When cellular pigment levels are relatively high, as in some heterotrophic dinoflagellates and metazoans, such as crustaceans (Hairston 1979, Byron 1982), the dominant pigment can be detected with only a few hundred ng of biomass. Adequate biomass should also be obtained from relatively low numbers of large ciliates (e.g. 200 Favella ehrenbergii), despite their characteristically high $\mathrm{C}$ :carotenoid ratios. Conversely, small ciliates with high $\mathrm{C}$ : carotenoid ratios need to be highly concentrated in order to be detected.

\section{Effects of light intensity}

As little as $10 \%$ of the incident ambient light is sufficient to cause photo-oxidation of proteins (Krinsky 1971). Carotenoids provide protection against photo-oxidation in a wide variety of organisms (Krinsky 1971, Hairston 1979). However, at the light intensities used in these experiments, the risk of photo-oxidation was minimal (cf. Krinsky \& Deneke 1982). Because carotenoids also fulfil a variety metabolic roles (Cheeseman 1967, Ringleberg 1980, Byron 1982), they might be expected to occur, perhaps at low concentrations, even when not required for photoprotection. In fact, higher average cellular pigment levels occurred in Gymnodinium sp. exposed to high light intensity. However, the large variability in pigment content between samples and the occurrence of pigment in cells exposed to low light suggest that factors other than, or in addition to, light intensity influenced the pigment levels in these protozoans.

One such factor may be food availability. Among metazoans, carotenoid biosynthesis is thought to be 
mediated by dietary precursors, such as beta-carotene (Katayama et al. 1973, Castillo et al. 1982). In the present study, canthaxanthin was detected in most cultures in which food (i.e. indicated by chlorophyll; Fig. 2) was present (cultures HB, HC, LD). Canthaxanthin was not detected in the relatively dense cultures that were processed after the food supply had been exhausted (cultures LA, LB, LC). The levels of canthaxanthin in Gymnodinium sp. covaried with chlorophyll from the algal food supply. It would appear that carotenoid pigment content was dependent upon food availability. In the absence of food, carotenoids were not present in Gymnodinium sp. Presumably the pigments were metabolized and could not be replaced.

Carotenoid levels in copepods also seem to be influenced by feeding activity, and carotenoid turnover rates can approach $100 \%$ per day (Hallegraeff et al. 1978, Kleppel et al. 1985). Starvation in cultures LA, LB and LC lasted up to $3 \mathrm{~d}$. This is sufficient time for pigment metabolism to colorless products, given the relatively high weight-specific metabolic rates of protozoans.

\section{CONCLUSION}

We have shown that protozoans contain astaxanthin and canthaxanthin, the same carotenoid pigments found in many metazoan zooplankton, but which are rarely reported in phytoplankton. Thus, the carotenoid composition of the protozoans is discernible from that of the phytoplankton. Further work is needed to determine whether carotenoids are ubiquitous among the microzooplankton, as well as to define the magnitude and sources of variability of cellular carbon : carotenoid ratios.

Protozoans and micrometazoans are abundant in the sea and important in marine food webs (Hunter 1981, Porter et al. 1985, Shapiro et al. 1989). Techniques for describing microzooplankton distributions are needed to augment traditional microscopic methods. It is worthwhile exploring the feasibility of using carotenoid pigments as biomarkers for microzooplankton, in much the same way as plant pigments are used to describe phytoplankton distributions. While probably not capable of providing the taxonomic detail of microscopy, carotenoid analysis is relatively rapid and precise. The instrumentation can be used on board ship, and the potential exists for near-real time data acquisition on microzooplankton pigment distributions. It is probable that, in the near future, efforts to describe microzooplankton distributions in the sea will include some form of carotenoid pigment analysis.
Acknowledgements. We are grateful to M. Murrell for assistance, and to R. R. Bidigare for providing canthaxanthin standards. We also appreciate the comments of J. Nelson and E. B. Sherr on the manuscript. The thoughtful comments of 2 anonymous reviewers helped us to avoid several errors in the analysis of the data and generally improved the manuscript. This work was supported by NSF grants OCE 88-22521 and OCE 89-16094 and by the Florida Sea Grant College through NOAA grant NA89 AA-D-SGO53.

\section{LITERATURE CITED}

Balch, W. M., Haxo, F. T (1984). Spectral properties of Noctiluca miliaris Suriray, a heterotrophic dinoflagellate. J. Plankton Res. 6: 515-525

Burkill, P. H., Mantoura, R. F. C., Llewellyn, C. A., Owens, N. J. P. (1987). Microzooplankton grazing and selectivity of phytoplankton in coastal waters. Mar. Biol. 93: 581-590

Byron, E. R. (1982). The adaptive significance of calanoid copepod pigmentation: a comparative experimental analysis. Ecology 63: 1871-1886

Carreto, J. J. (1985). A new keto-carotenoid from the dinoflagellate Protoperidinium depressum (Bayley) Balech 1974. J. Plankton Res. 7: 421-423

Castillo, R., Negres-Sadargues, G., Lenel, R. (1982). General survey of carotenoids in Crustacea. In: Britton, G., Goodwin, T W. (eds.) Carotenoid chemistry and biochemistry. Oxford University Press, London, p. 211-224

Cheeseman, D. F., Lee, W. L., Zegalsky, P. F. (1967). Carotenoids in invertebrates. Bio. Rev. 42:132-160

Davies, B. H. (1976). Carotenoids. In: Goodwin, T W. (ed.) Chemistry and biochemistry of plant pigments, 2 nd edn. Academic Press, London, p. 38-165

Gifford, D. (1985). Laboratory culture of marine planktonic oligotrichs (Ciliophora, Oligotrichida). Mar. Ecol. Prog. Ser. 23: 257-267

Goodwin, T. W. (ed.) (1976). Chemistry and biochemistry of plant pigments, 2nd edn. Academic Press, New York

Hairston, N. J. Jr (1979). The adaptive significance of color polymorphism in two species of Diaptomus (Copepoda). Limnol. Oceanogr. 24: 15-37

Hallegraeff, G. M., Mous, L. J., Veeger, R., Flick, J. G., Ringelberg, J. (1978). A comparative study of carotenoid pigmentation of the zooplankton of Lake Marseveen (Netherands) and Lac Pavin (Auvergne, France). 2. Diurnal variations in carotenoid content. Comp. Biochem. Physiol. 60: 59-62

Herring, P. J. (1968). The carotenoid pigments of Daphnia magna Straus. II. Aspects of pigmentary metabolism. Comp. Biochem. Physiol. 24: 205-221

Herring, P. J. (1972). Depth distribution of carotenoid pigments and lipids of some oceanic animals. I. Mixed zooplankton, copepods and euphausids. J. mar. biol. Ass. U.K. 52: $179-189$

Hunter, J. R. (1981). Feeding ecology and predation of marine fish larvae. In: Lasker, R. (ed.) Marine fish larvae. Morphology, ecology and relation to fisheries. Univ. Washington Sea Grant, Seattle, p. 33-77

Katayama, T. Kunisaki, Y., Shimaya, M., Simpson, K. L. Chichester, C.O. (1973). The biosynthesis of astaxanthin. XIV. The conversion of labeled $\beta$-carotene- $15-15^{3} \mathrm{H}$ into astaxanthin in the crab Portunus tuberculatus. Comp. Biochem. Physiol. 24: 205-221

Kleppel, G. S. (1988). Plant and animal pigments as trophodynamic indicators. In: Soule, D. F., Kleppel, G. S. (eds.) 
Marine organisms as indicators, Springer-Verlag, New York, p. 73-90

Kleppel, G. S., Frazel, D. W., Pieper, R. E., Holliday, D. V. (1988). Natural diets of zooplankton off southern California. Mar. Ecol. Prog. Ser. 49: 231-241

Kleppel, G. S., Willbanks, L., Pieper, R. E. (1985). Diel variation in body carotenoid content and feeding activity in marine zooplankton assemblages. J. Plankton Res. 7: $569-580$

Krinsky, N. I. (1971). Function. In: Isler, O. (ed.) Carotenoids. Birkhauser, Basel, p. $669-716$

Krinsky, N. I., Deneke, S. M. (1982). Interaction of oxygen and oxy-radicals with carotenoids. J. natn. Cancer Inst. 69: 205-209

Lessard, E. J. (1991). The trophic role of heterotrophic dinoflagellates in diverse marine environments. Mar. microb. Fd Webs 5: 49-58

Liảaen-Jensen, S. (1979). Carotenoids - a chemosystematic approach. Pure \& appl. Chem. 51: 661-675

Mantoura, R. F. C., Llewellyn, C. A. (1983). Rapid determination of algal chlorophyll and carotenoid pigments and their degradation products in natural waters by reversephase high performance liquid chromatography. Analytica chim. Acta 151: 297-314

McManus, G. B., Fuhrman, J A. (1986). Photosynthetic pigments in the ciliate Laboea strobila from Long Island Sound, USA. J. Plankton Res. 8: 317-327

Neveaux, J. Soyer, M.-O. (1976). Characterisation des pigments et structure fine de Protoperidinium ovatum Pouchet (dinoflagellata). Vie Milieu 26: 175-199

Porter, K. G., Sherr, E. B., Sherr, B. F., Pace, M., Sanders, R. W. (1985). Protozoa in planktonic food webs. J. Protozool. 32 : 409-415

Putt, M., Stoecker, D. K. (1989). An experimentally determined carbon:volume ratio for marine (oligotrichous)

This article was presented by E. \& B. Sherr, Corvallis, Oregon, USA ciliates from estuarine and coast waters. Limnol. Oceanogr. 34: 1097-1103

Ringelberg, J (1980). Aspects of red pigmentation in zooplankton, especially copepods. In: Kerfoot, W. C. (ed.) Evolution and ecology of zooplankton communities. University of New Hampshire Press, Hanover, p. 91-97

Shapiro, L., Haugen, E. M., Carpenter, E. J. (1989). Occurrence and abundance of green-fluorescing dinoflagellates in surface waters of the Northwest Atlantic and Northeast Pacific Oceans. J. Phycol. 25: 189-191

Sherr, E. B., Sherr, B. F., Paffenhofer, G.-A. (1986). Phagotrophic protozoans as food for metazoans: a missing trophic link in marine pelagic food webs. Mar. microb. Fd Webs 1: $61-80$

Smith, R. C., Bidigare, R. R., Prezlin, B. B., Baker, K. S., Brooks, J. M. (1987). Optical characterization of primary productivity across a coastal front. Mar. Biol. 96: 575-591

Snyder, L. R., Kirkland, J J. (1979). Introduction to modern liquid chromatography, 2nd edn. John Wiley, New York

Stoecker, D. K., Capuzzo, J. M. (1990). Predation on protozoa: its importance to zooplankton. J. Plankton Res. 12: $891-908$

Stoecker, D. K., Michaels, A. E., Davis, L. H. (1987). Large proportion of marine planktonic ciliates found to contain functional chloroplasts. Nature, London 326: 790-792

Strain, H. H., Manning, W. M., Harding, G. (1944). Xanthophylls and carotenes of diatoms, brown algae. dinoflagellates and sea anemones. Biol. Bull. mar. biol. Lab., Woods Hole 86: 169-191

Withers, N. W., Cox, E. R., Tomas, R., Haxo, F. T. (1977). Pigments of the dinoflagellate Peridinium balticum and its photosynthetic endosymbiont. J. Phycol. 13: 354-358

Withers, N., Haxo, F. T (1978). Isolation and characterization of carotenoid-rich lipid globules of Peridinium foliaceum. Plant Physiol., Lancaster. 62: 36-39

Manuscript first received: March 21, 1992

Revised version accepted: June 4, 1992 